\title{
Economic Globalisation, Growth and the Environment: Testing of Environment Kuznet Curve Hypothesis for Malaysia
}

\section{Ram N. Agarwal*}

OYA Graduate School of Business, University Uttara Malaysia, Malaysia

\begin{abstract}
Economic liberalization-growth-Environment nexus is well known but debatable and an open question in the economic literature. Results regarding this nexus are not straight forward but they are sometimes confusing and contradicting. Some studies have found that the two key elements of globalization viz. trade liberalization and inflow of Foreign Direct Investment (FDI) have a positive impact on economic growth, while others have seriously questioned the significance of this result. Likewise studies have been conducted to investigate the impact of trade liberalization and FDI inflow on environment and the results remain inconclusive. There are numerous studies investigating the impact of trade and FDI on economic growth. But few studies exist that have analyzed the joint impact of FDI and trade liberalization policies on environment. The present study fills this gap by introducing explicitly and jointly the two major elements of globalization namely trade liberalization and the inflow of FDI into the analysis. Annual data from 1980 to 2008 from the World Bank data base has been used. To start with, the paper explores the causal relationship between FDI, trade, and Gross Domestic Product (GDP) growth. Also variables are tested for the degree of stationarity and co integration. Then Autoregressive Distributed Lag (ARDL) approach to co-integration techniques has been used to capture the impact of short-run dynamics and long-run equilibrium.
\end{abstract}

The study finds that economic liberalization policies have been helpful for the growth of the Economy. The growth environment nexus via the Environment Kuznet Curve Hypothesis (EKC) for Malaysia is confirmed by the study. Further, the results do not suggest that trade liberalization policies have directly affected environment. Pollution Heaven hypothesis is also not fully supported by the data.

Keywords: Economic globalization; Foreign direct investment; Trade liberalization; Growth; Pollution haven hypothesis; Environment kuznets curve hypothesis

\section{Introduction}

Since the early 1980s there has been considerable progress in trade reforms and the flow of foreign capital especially in the form of Foreign Direct Investment (FDI) in most developing countries. These countries have moved from an import substitution strategy to an export-oriented approach, resulting in an unprecedented increase in both trade (exports) and foreign capital flows. However, the extent of liberalization of economic policies and integration with the global economies (globalization) has been different for the different countries in the developing world. In particular, Malaysia has been successful in attracting FDI and followed an export-led growth policy since the early 1980s. Most of the earlier empirical research about the effects of liberalization process on the economy has treated trade (exports) as the principal channel through which openness can affect the output level and eventually the rate of economic growth, that is, the Export-Led Growth Hypothesis (ELG). However, it has been recognized recently in the literature on development economics that international capital flows and especially Foreign Direct Investment (FDI) is another relevant component of outward oriented policies that can raise economic growth through transfer of modern technology, by improving factor productivities and by providing finances much required in the developing countries. Data related to the flow of foreign capital supports the literature. Foreign Direct Investment (FDI) has grown dramatically in the past twenty years exceeding the growth of the world production and the growth of international trade. Although most FDI is concentrated in the developed world, FDI flows have become increasingly significant for many developing countries. Since 1980, FDI to developing economies has increased over 20-fold [1]. Today, FDI typically accounts for more than 60 percent of private capital flows to the developing world [2]. This world-wide explosion of FDI was accompanied by a shift in emphasis among policymakers in developing countries to attract more foreign capital. Most countries have reduced barriers to FDI and many aggressively offered tax incentives and subsidies. The simple rationale for the increased efforts to attract FDI stems from believing that FDI promotes growth. However, most of the earlier studies have considered either trade or FDI as the engine of growth but do not include FDI inflows along with trade in their growth analysis, in spite of the fact that these FDI flows have been growing at a pace far exceeding the growth in international trade during the last two decades. Since 2000 many studies have appeared in the literature that has considered both the major components of globalization for their effect on economic growth. For instance a study by Alguacil MT et al. [3] on the Mexican economy has revealed that outward looking policies involve more than just trade. Their results confirm not only the ELG hypothesis but also the existence of FDI-growth nexus. Furthermore, their study points to a positive causal relationship from FDI to exports suggesting a kind of FDI led exports- growth linkages.

Another question being debated in the economic literature is about the impact of these liberalized policies on environment. According to the standard trade theory, trade in goods worsens environmental quality in countries that have a comparative advantage in the production

${ }^{*}$ Corresponding author: Ram N. Agarwal, Visiting Professor of Economics and Finance, OYA- Graduate School of Business, University Uttara Malaysia, Malasiya, Tel: +604-9285207, +6013-5257536; E-mail: ram_ieg@yahoo.co.in

Received May 25, 2012; Accepted June 17, 2012; Published June 21, 2012

Citation: Agarwal RN (2012) Economic Globalisation, Growth and the Environment: Testing of Environment Kuznet Curve Hypothesis for Malaysia. J Bus Fin Aff 1:104. doi:10.4172/2167-0234.1000104

Copyright: (c) 2012 Agarwal RN. This is an open-access article distributed under the terms of the Creative Commons Attribution License, which permits unrestricted use, distribution, and reproduction in any medium, provided the original author and source are credited. 
of polluting goods. The comparative advantage may arise due to the distribution of the world endowments of the factors of production or from the differences in pollution related norms. Similarly, the relationship between FDI and the environment has received considerable attention in the recent past. The theory underlying this body of work is the pollution heaven hypothesis. Unfortunately, in an effort to accelerate economic growth, environmental considerations have been kept as a secondary objective in policy making in most of the developing countries including India and Malaysia. This indifference towards environmental protection has led to serious environmental problems in developing countries, threatening their sustainable future. One group of studies has analyzed the impact of exports on environment via economic growth. This approach of looking at the impact of economic growth on environment is popularly known as Environmental Kuznets Curve (EKC). The second group of studies has attempted to investigate the impact of FDI on the environment in developing countries which is referred to as the FDI-Environment nexus the impact on environment could be through the shifting of dirty industries from the advanced countries to the developing countries and due to their comparatively lower levels of pollution norms (Pollution Heaven Hypothesis). However, the impact could also be indirect through the impact of FDI on exports and economic growth. The literature is deficient in this type of studies and the present study aims at filling this gap.

\section{Major objectives of the study}

The first major objective of this paper is to analyze the impact of openness (globalization) of the economy in terms of trade liberalization and inflow of foreign capital on economic growth. Second objective is to test the Environment Kuznets Curve Hypothesis and Pollution Heaven Hypothesis. The third major objective is to analyze the impact of economic globalization on environment using an econometric model (ARDL Model).

The paper is structured as follows - A brief description of economic liberalization policies in Malaysia and the status of its trade, FDI flows, economic growth and environment is presented in keywords. The theoretical framework is described in Introduction. A short literature review is presented in Economic Liberalization Policies in Malaysia since 1980s and the Status of its Trade, Capital Flows (FDI) and Environments. Model is specified in Theoretical Framework. The empirical results are presented in Literature Review, and finally some conclusions and policy implications are drawn in Model Specification.

\section{Economic Liberalization Policies in Malaysia since 1980s and the Status of its Trade, Capital Flows (FDI) and Environments}

The Economy of Malaysia is a growing and relatively open stateoriented and newly industrialized market economy. The state plays a significant but declining role in guiding economic activity through macroeconomic plans. In 2007, the economy of Malaysia was the 3rd largest economy in South East Asia and 28th largest economy in the world by purchasing power parity with gross domestic product for 2008 of $\$ 222$ billion with a growth rate of $5 \%$ to $7 \%$ since 2007. In 2010, GDP per capita (PPP) of Malaysia stands at US\$14,700. In 2009, the nominal GDP was US $\$ 383.6$ billion, and the nominal per capital GDP was US\$8,100.

${ }^{1}$ Understanding Multicultural Malaysia published by Pearson Malaysia, 2003 by Abdullah, Asma and Pederson, paul B; Economy of Malaysia (2010) Bank Negara Malaysia.
The South East Asian nation experienced an economic boom and underwent rapid development during the late $20^{\text {th }}$ century and has a GDP per capita of $\$ 14,800$, being considered a newly industrialized country. On the income distribution, there are 5.8 million households in 2007. Of that, $8.6 \%$ have a monthly income below RM1,000, $29.4 \%$ had between RM1,000 and RM2,000, while 19.8\% earned between RM2,001 and RM3,000; $12.9 \%$ of the households earned between RM3,001 and RM4,000 and 8.6\% between RM4,001 and RM5,000. Finally, around $15.8 \%$ of the households have an income of between RM5,001 and RM10,000 and 4.9\% have an income of RM 10,000 and above.

As one of three countries that control the Strait of Malacca, international trade plays a large role in its economy. At one time, it was the largest producer of tin, rubber and palm oil in the world. Manufacturing has a large influence in the country's economy. Malaysia is the world's largest Islamic banking and financial centre. Since it became independent in 1957, Malaysia's economic record has been one of Asia's best. Real Gross Domestic Product (GDP) grew by an average of $6.5 \%$ per year from 1957 to 2005. Performance peaked in the early 1980s through the mid-1990s, as the economy experienced sustained rapid growth averaging almost $8 \%$ annually. High levels of foreign and domestic private investment played a significant role as the economy diversified and modernized. Once heavily dependent on primary products such as rubber and tin, Malaysia today is a middleincome Economy of Malaysia a country with a multi-sector economy based on services and manufacturing. Malaysia is one of the world's largest exporters of semiconductor components and devices, electrical goods, solar panels, and Information and Communication Technology (ICT) products. Malaysia's capital market crossed the RM2 trillion thresholds for the first time ever as at end-2010. The capital market had achieved an annual compounded growth rate of $11 \%$ from RM717bil in 2000 due to rapid industry expansion and strong regulatory oversight that underpinned investor confidence in the Malaysian capital market ${ }^{1}$.

The data reveal that GDP per capita has risen continuously from RM 1802 in 1980 tom 8066 in 2008. Environment pollution as measured by the emission of $\mathrm{CO}_{2}$ per capita has also increased from 202 Kilo Metric Tons (KMT) in 1980 to 7.57 KMT in 2008. During the same period FDI has remained stagnant and FDI intensity has actually fallen. On the other hand trade intensity has increased significantly from a level of 95.3 to 186.4 (Table 1 ).

\section{Theoretical Framework}

\section{Globalization and economic growth}

In theory there are several potential ways in which FDI and trade liberalization can cause economic growth. Solow-type standard neoclassical growth models suggest that FDI increases the capital stock and thus growth in the host economy by financing capital formation accordingly, the impact of FDI on growth is identical to that of domestic investment. In endogenous growth models, in contrast, FDI is often assumed to be more productive than domestic investment. The logic behind this is that FDI encourages the incorporation of new technologies in the production function of the host economy [4]. In this view, FDI-related technological spillovers offset the effects of diminishing returns to capital and keep the economy on a long-term growth path. Moreover, endogenous growth models imply that FDI can promote long-run growth by augmenting the existing stock of knowledge in the host economy through labor training and skill acquisition, on the one hand, and through the introduction of alternative management 


\begin{tabular}{|c|c|c|c|c|c|c|c|}
\hline Obs & CO2PERCAPITA & GROWTH & GDP PERCAP & FDIINT & FDI & IND Share & TRADEINT \\
\hline 1980 & 2.024028 & 7.444234 & 1802.775 & 3.745047 & $9.34 \mathrm{E}+08$ & 41.03946 & 95.35212 \\
\hline 1981 & 2.174016 & 6.941952 & 1795.861 & 4.966761 & $1.26 E+09$ & 40.31747 & 91.68584 \\
\hline 1982 & 2.102287 & 5.940927 & 1876.418 & 5.120342 & $1.40 \mathrm{E}+09$ & 37.88437 & 89.51462 \\
\hline 1983 & 2.54408 & 6.250251 & 2055.708 & 4.108287 & $1.26 \mathrm{E}+09$ & 38.52562 & 89.06687 \\
\hline 1984 & 2.263064 & 7.761925 & 2254.5 & 2.307124 & $7.97 E+08$ & 38.52702 & 88.69737 \\
\hline 1985 & 2.298904 & -1.12225 & 2015.64 & 2.186539 & $6.95 \mathrm{E}+08$ & 38.52782 & 87.31835 \\
\hline 1986 & 2.465139 & 1.152509 & 1741.234 & 1.73095 & $4.89 \mathrm{E}+08$ & 38.5272 & 87.01593 \\
\hline 1987 & 2.440606 & 5.388645 & 1926.846 & 1.313417 & $4.23 E+08$ & 38.52747 & 95.2094 \\
\hline 1988 & 2.483956 & 9.937724 & 2050.683 & 2.039636 & $7.19 \mathrm{E}+08$ & 38.35661 & 106.7734 \\
\hline 1989 & 2.817433 & 9.058481 & 2194.234 & 4.293264 & $1.67 \mathrm{E}+09$ & 39.80405 & 122.3958 \\
\hline 1990 & 3.108033 & 9.009649 & 2417.773 & 5.298123 & $2.33 E+09$ & 42.19817 & 133.3585 \\
\hline 1991 & 3.666456 & 9.545465 & 2626.387 & 8.137869 & $4.00 \mathrm{E}+09$ & 42.10682 & 144.4971 \\
\hline 1992 & 3.920945 & 8.885116 & 3080.141 & 8.762883 & $5.18 \mathrm{E}+09$ & 41.14626 & 136.3064 \\
\hline 1993 & 4.655675 & 9.894947 & 3395.44 & 7.482897 & $5.01 \mathrm{E}+09$ & 40.08467 & 138.6976 \\
\hline 1994 & 4.65275 & 9.212043 & 3686.175 & 5.829422 & $4.34 \mathrm{E}+09$ & 40.04144 & 159.0262 \\
\hline 1995 & 5.845911 & 9.829082 & 4287.113 & 4.703506 & $4.18 E+09$ & 41.40206 & 170.664 \\
\hline 1996 & 5.900792 & 10.0027 & 4746.614 & 5.035523 & $5.08 \mathrm{E}+09$ & 43.52804 & 155.4211 \\
\hline 1997 & 5.730598 & 7.322743 & 4598.804 & 5.127856 & $5.14 \mathrm{E}+09$ & 44.57354 & 157.5041 \\
\hline 1998 & 5.115331 & -7.35942 & 3233.306 & 2.997426 & $2.16 \mathrm{E}+09$ & 43.87576 & 182.3671 \\
\hline 1999 & 4.719954 & 6.13761 & 3461.145 & 4.921467 & $3.90 \mathrm{E}+09$ & 46.45901 & 188.7858 \\
\hline 2000 & 5.406947 & 8.858868 & 4005.556 & 4.038429 & $3.79 \mathrm{E}+09$ & 48.32057 & 192.1234 \\
\hline 2001 & 5.704942 & 0.517675 & 3871.705 & 0.597029 & $5.54 \mathrm{E}+08$ & 46.20269 & 174.4601 \\
\hline 2002 & 5.51202 & 5.390988 & 4113.571 & 3.176562 & $3.20 E+09$ & 45.11538 & 172.4687 \\
\hline 2003 & 6.395254 & 5.788499 & 4397.508 & 2.244197 & $2.47 \mathrm{E}+09$ & 46.57866 & 170.6 \\
\hline 2004 & 6.566522 & 6.783438 & 4874.844 & 3.706798 & $4.62 E+09$ & 48.53032 & 185.8076 \\
\hline 2005 & 7.028492 & 5.332139 & 5281.495 & 2.877085 & $3.97 E+09$ & 49.71332 & 185.4249 \\
\hline 2006 & 6.748553 & 5.848859 & 5887.375 & 3.881924 & $6.08 \mathrm{E}+09$ & 49.68979 & 186.4439 \\
\hline 2007 & 7.205588 & 6.480192 & 6899.603 & 4.602489 & $8.59 \mathrm{E}+09$ & 47.49606 & 173.1621 \\
\hline 2008 & 7.572802 & 4.708289 & 8065.9 & 3.325051 & $7.38 \mathrm{E}+09$ & 48.06892 & 160.6698 \\
\hline
\end{tabular}

Table 1: GDP, GDP Growth, FDI Intensity, Trade Intensity and $\mathrm{CO}_{2}$ per Capita in Malaysia.

practices and organizational arrangements, on the other [5]. In this context it is also argued that multinational companies, through FDI, may also diffuse their knowledge of global markets to domestic firms and hence enable them to become more successful exporters. Hence, through capital accumulation and knowledge spillovers, FDI may play an important role for economic growth. However, it is argued that FDI in the form of mergers and acquisitions do not necessarily increase the capital stock in capital-scarce economies. Cross-border mergers and acquisitions merely represent a transfer of existing assets from domestic to foreign hands. If the proceeds of the sales of these assets are spent on consumption, FDI does not contribute to capital formation and growth. More importantly, the positive effect of FDI on growth through capital accumulation requires that FDI does not "crowd out" equal amounts of investment from domestic sources. Accordingly, FDI may actually harm the host economy when foreign investors claim scarce resources (such as import licenses, skilled manpower, credit facilities, etc.) or foreclose investment opportunities for local investors. Additionally, there is also concern that the positive knowledge spillovers predicted by endogenous growth models do not occur in developing countries. For example, Görg and Greenaway [6] critically review a number of firmlevel studies on productivity spillovers in manufacturing industries in developing, developed and transition economies. They report that only six out of 25 studies using appropriate data and estimation techniques find some positive evidence of spillovers running from foreign-owned to domestic owned firms, none of which is for developing countries. Aitken and Harrison [7] for Venezuela - actually find some evidence of negative effects of the presence of multinationals firms. Several explanations have been offered to explain these negative or statistically insignificant results. The most plausible explanation for the negative effects is that foreign firms reduce the productivity of domestic firms through competition effects, as suggested by Aitken and Harrison [7]. They argue that multinationals have lower marginal costs due to some firm specific advantage, which allows them to attract demand away from domestic firms, forcing them to reduce their production and move up their average cost curve. Furthermore, FDI is often associated with firm restructuring according to the production chain of the multinational company, which implies that raw materials and other inputs are purchased within the multinational enterprise and thus from foreign rather than local suppliers. As a consequence, the production of local suppliers may shrink. Despite these potential negative effects, the empirical evidence generally suggests that FDI has a positive impact on economic growth in developing countries, as recent surveys by Hansen and Rand [8] attest. Admittedly, the size of the impact of FDI on growth seems to depend on economic and political conditions in the host country, such as the level of per capita income, the human capital base, the degree of openness in the economy, and the extent of the development of domestic financial markets.

\section{Globalization and environment}

There are two schools of thought about the relationship between globalization and environment. One preposition is that trade between countries with similar ratios of factor endowments worsens the environment by shifting pollution intensive industries to low regulation (low income) countries. This is known as Pollution Heaven Hypothesis (PHH). However, the earliest empirical work has found little evidence in support of PHH. Nevertheless, subsequent empirical research [9] has found evidence of a weak relationship between regulatory norms and 
trade. This is called Pollution Heaven effect (PHE). Similarly, countries with similar environmental standards, a country that is abundant in the capital that is used in the production of the polluting good compared to the rest of the world, will expand the production of polluting good under free trade. But when the ratios of factor endowments differ along with environmental norms across countries then the net effect will depend upon the relative strength of each effect.

The second preposition is that trade affects environment directly and indirectly. The indirect effect can take place through three principal channels: the composition, scale and technique effects. These effects arise due to changes in relative prices which in turn arise on account of integration with the global economy. On the other hand direct effect comes because of increases in emissions especially from the transport sector which is responsible for moving goods and services between countries.

The scale effect refers to the scale of the economy. As the scale of economy grows, environment quality is likely to fall initially and then might improve later on. Efficient allocation of resources within countries raises the size of the industrial pollution base resulting in greater global emissions. The Composition effect measures changes in emission from the change in a country's industrial composition following trade liberalization. This is measured by the share of the dirty industries in the total industrial output. How much a country emits per unit of a good produced or consumed depend on the techniques of production or consumption. The technique effect refers to the channels through which globalization process brings the technology and pollutes the environment. For instance, pollution intensity of the dirty industry represents the technique effect. The technique effect may arise due to technology transfer or due to trade induced innovations.

Again, as explained above, when FDI is allowed to move across countries it will also affect environment depending upon the differences in environmental regulations and factor endowments between the countries. For instance, a country with less stringent environmental regulations will attract capital and lead to an expansion of production in the polluting industry.

Hence, the impact of trade liberalization and inflow of FDI may be diverse and their combined effect is uncertain. If the pollution heaven hypothesis plays the major role in trade, then an increase in FDI will amplify the effect. On the other hand if the factor endowments play the major role in trade, then the effect of inward FDI will be opposite from that of free trade. thus, the combined impact of trade liberalization and FDI inflow on environment can be analyzed by including all the relevant variables as regressors independently and directly like economic growth, trade intensity, flow of FDI, industrial growth, share of pollution intensive industries in the total industrial output, etc., The model is specified as under:

\section{Literature Review}

\section{On trade liberalization-growth nexus}

Substantial literature has developed on the effects of trade liberalization on various aspects of the macro economy of a country including its economic growth. Major reviews published include Edwards [10], Krueger [11], Rodriguez and Rodrik [12]. Examples of time series analysis include Harrigan and Mosley [13], Papageorgiou et al. [14], Greenaway and Sapsford [15], Harrigan and Mosley [13]. The study by Papageorgiou et al. [14] reports the most favourable growth enhancing effects for liberalization. Who evaluate 36 liberalization episodes in 19 Countries and conclude that more rapid growth of real
GDP is secured with minimal transitional costs in unemployment and fiscal constraints. However, the conclusions have been challenged by Greenway largely on the grounds that the underlying measure of liberalization is not proper. Greenaway et al. [16] look specifically at the timing of the Papageorgiou et al. [14] episodes and find no systematic evidence of a connection between trade reforms and growth acceleration. Rodriquez and Rodrik [12] show, many of the reported results are not very robust to changes in specification. Thus, establishing whether or not policies related to liberalization of trade have impacted on growth is not straightforward. The results have been questioned on three grounds. Is it sensible to assume a continuation of pre-existing policies and performance? Second, how does one disentangle the effects of trade reforms from other effects? Third, supply responses will differ from economy to economy: how long should one wait before conducting an assessment of reforms?

Also there is the familiar causality issue between exports and GDP. The direction of causality is very important in econometric analysis. The first causality is described from exports to economic growth and is called the export led growth hypothesis [17]. Maki and Somwaru argue that export growth increases factor productivity due to increasing returns to scale by catering to the larger market, and relaxes the foreign exchange constraint for importing the modern technology and components. The other equally appealing causality is explained by output growth led export growth theory [18]. According to the latter theory the domestic market may not be sufficient for the increased output and thus the exporters have to look outward to sell their products.

\section{FDI-Growth nexus}

Large number of studies has been conducted on the effects of FDI on economic growth in developing countries over the last three decades. The first group of studies has provided the theoretical rationale of the effect of FDI inflows on economic growth which is known as the FDIgrowth nexus $[19,20]$. Empirical studies from both cross country and country specific experiences have pointed to Foreign Direct Investment (FDI) as being critical in promoting growth. For instance, it is described in the literature that there are two main channels through which FDI may be growth enhancing [5]: First, FDI can encourage the adoption of new technology in the production process through capital spillovers. Second, FDI may stimulate knowledge transfers, both in terms of labor training and skill acquisition and by introducing alternative management practices and better organizational arrangements.

Marwah and Tavakoli [21] also have examined the effect of FDI and imports on economic growth in four ASEAN countries. The elasticity of the estimated production function of FDI was found to be significant in explaining the economic growth of all the four countries. Estimated foreign capital elasticity was found to be 0.086 while import contributed 0.443 to growth in the case of Malaysia. Clearly, they conclude that both FDI and imports had a significant impact on growth.

De Mello [5] conducted time series as well as panel data estimation. He included a sample of 15 developed and 17 developing countries for the period 1970-90. The study found strong relationship between FDI, capital accumulation, output and productivity growth. The time series estimations suggest that the effect of FDI on growth or on capital accumulation and Total Factor Productivity (TFP) varies greatly across countries. The panel data estimation indicated a positive impact of FDI on output growth in both developed and developing country subsamples. However, the effect of FDI on capital accumulation and TFP growth varies across developed (technological leaders) and developing 
countries (technological followers). FDI has a positive effect on TFP growth in developed countries but a negative effect in developing countries. This pattern is however, reversed in the case of effect on capital accumulation. De Mello [5] infers from these findings that the extent to which FDI is growth-enhancing depends on the degree of complementarities between FDI and domestic investment.

A study by $\mathrm{Li}$ and Liu [22] has used the panel data of 84 countries to investigate the influence of FDI on growth. The study found a significant relationship between FDI and economic growth. Additionally, a stronger relationship was extracted when FDI was interacted with human capital. This is because stronger human capital poses better absorptive capacities due to the complementary nature of FDI and human capital, especially in developing countries. In contrast, there have been several studies indicating a negative or no relationship between FDI and growth.

\section{Economic Growth - environment nexus}

The impact of economic growth on environment has been studied over the years by several researchers like Grossman and Krueger [23], Seldon and Song [24], Antweiler et al. [25]. This approach of looking at the impact of economic growth on environment is popularly known as Environmental Kuznets curve (EKC). Simon Kuznets [26,27] postulated an inverted $\mathrm{U}$ - shaped relationship between economic development and economic inequality. The application of EKC concept to the relationship between economic development and environmental quality postulates that environment conditions deteriorate in the early stages of development through industrialization and that environment conditions improve as countries develop and reach a certain minimum level of per capita income. There exist several studies like Dean [28], Copeland and Taylor [29], which has analyzed the impact of trade liberalization policy on economic growth and environment. Majority of studies have supported the EKC hypothesis.

\section{FDI-Environment nexus}

The second group of studies has attempted to investigate the impact of FDI on the environment in developing countries which is referred to as the FDI-environment nexus [30]. The impact on environment could be direct through the shifting of dirty industries from the advanced countries to the developing countries and due the comparatively lower levels of pollution norms (Pollution Heaven Hypothesis) or through the impact of FDI on economic growth. Unlike a vast amount of literature that has been conducted on FDI-growth nexus, empirical studies on FDI-Environment nexus are still relatively sparse and has been rather mixed both in the developed and developing countries. For instance, Xing and Kolstad [31] have examined the effect of FDI on environmental quality in both developed and developing countries. They find a weak support for the pollution heaven hypothesis that developing countries tend to utilize lax environmental regulations as a strategy to attract dirty industries from developed countries. Eskeland and Harrison [32] report that foreign owned plants are found more energy efficient and use cleaner type of energy than domestically owned. He [33] has explored the relationship between FDI and the environment in China and found that an increase in FDI inflows results in deterioration of environmental quality. However, these studies implicitly assume a one-way causality from measures of environmental quality (SO2 and $\mathrm{CO}_{2}$ emissions) and/or economic growth (GDP) to FDI and adopt a structural model (i.e., reduced form equations) to estimate the impacts of FDI based on such causality. Baek and Koo [34], using cointegration analysis and a Vector Error Correction (VEC) model, have examined the short and long run relationships among Foreign Direct Investment
(FDI) economic growth and the environment in China and India. The results show that FDI inflows play a pivotal role in determining the short and long-run movement of economic growth through capital accumulation and technical spillovers in the two countries. However, a FDI inflow in both countries was found to have a detrimental effect on environmental quality in both the short- and long-run. Also, they found that, in the short-run, there exists a unidirectional causality from FDI inflows to economic growth and the environment in China and India a change in FDI inflows causes a change in environmental quality and economic growth but the obverse does not hold. Acharyya [35] has recently examined the two most important benefits and costs of foreign direct investment in the Indian context GDP growth and the environment degradation. He finds a statistically significant long run positive but marginal, impact of FDI inflows on GDP growth in India during 1980-2003. On the other hand the long run growth impact of FDI inflows on $\mathrm{CO}_{2}$ emissions is also found to be substantial.

\section{Model Specification}

Most of the empirical research about the effects of this liberalization process has treated exports (or total trade) as the principal channel through which openness can affect the output level and eventually the rate of economic growth, that is, The Export-Led Growth Hypothesis (ELG). Then the flow of foreign capital in the form of FDI and domestic investment also helps in economic growth. The growth equation is thus specified as under;

Growth $=\mathrm{f}($ Trade Intensity, FDI/GDP, Domestic Investment/GDP) (i)

Again, as discussed above in theory and supported by the literature review, there seems to exist a relationship between globalization and environmental pollution. The relationship is specified below.

Environment pollution $=\mathrm{f}($ Real GNP per capita, Real GNP per capita $\left.^{2}\right)$

Environment pollution $=\mathrm{f}(\mathrm{FDI} / \mathrm{GDP}$, Trade $/$ GDP $)$

Environment pollution $=\mathrm{f}(\mathrm{FDI} / \mathrm{GDP}$, Real GNP per capita, Industry Output/GDP, Polluting Industries output / Industry output, Trade/GDP)

\section{Limitations of data and variables used in the study}

- The study is based on the annual data for the period 1982 to 2008 obtained from the World Bank data source of World Bank/International Monetary Fund (IMF). Quarterly data for the entire period is not available for Malaysia.

\section{- Trade liberalization}

Even at the conceptual level, liberalization is not unambiguous. In the simple trade model, one naturally thinks of it as tariff liberalization. In a more sophisticated setting with instruments affecting the domestic prices of both importable and exportable, one can conceive of it as a move towards relative price neutrality. Finally, one can think of second best liberalization, i.e. the substitution of more efficient for less efficient instruments - typically tariffs for quotas. This ambiguity is reflected in the range of measures used empirically. A widely used indicator is changes in nominal tariffs. An alternative is to combine information on changes in a range of trade policy measures to compute some kind of index of liberalization. This strategy acknowledges that, in practice, trade reforms are multi-faceted, and it has been adopted by, for example, Papageorgiou et al. [14], IMF. Because they have a high information content such indexes can be a rich resource. Their key 
constraint is that, having a degree of subjectivity, they are less valuable when it comes to comparative analysis.

To avoid subjectivity in the measurement of index, trade intensity has been used here as more practical and suitable measure of trade liberalization. Trade intensity is measured as ratio of total trade volume (Exports + Imports) to GDP.

Trade Intensity $=($ Exports of goods + imports of goods $) /$ GDP

National Income

This is measured as the real GDP per capita

\section{Economic Growth (Growth)}

This is measured as the growth rate of real GDP.

\section{Environment pollution intensity $\left(\mathrm{CO}_{2}\right.$ per capita)}

Pollution intensity is measured by the carbon dioxide $\left(\mathrm{CO}_{2}\right)$ in tones emitted in the environment due to economic activities per person, although this is not a perfect measure of environment pollution. In the absence of continuous data on Environmental Sustainability index was developed by the United Nations, $\mathrm{CO}_{2}$ emission per capita has been used as the second best alternative. Again, there are several gases produced by the economic activities in the country such as carbon mono oxide, sulphur di oxide and other green house gases but they are difficult to be measured. At the international level data on carbon di oxide is only available. So its intensity is taken as a measure of pollution.

\section{FDI intensity}

Net flow of foreign capital in the Form of Direct Investment (FDI) as a percentage of GDP is measured as FDI intensity. Other forms of flow of foreign capital like foreign portfolio capital and bonds are not considered for their impact on environment as it is assumed that these forms of foreign capital flows are generally invested in financial investments and not in physical investment like FDI.

\section{Model estimation (ARDL Approach)}

To start with, the relevant variables like economic growth, inflow of foreign direct investment trade intensity and the level of pollution intensity as measured by $\mathrm{CO}_{2}$ emissions per capita are tested for stationarity and co-integration. Then the environment model is estimated using ARDL approach. This has been done because in applying the co-integration technique and ECM model, we need to determine the order of co-integration of each variable and as noted in the literature, depending upon the power of unit root tests, different tests yield different results. In view of this problem, Pesaran and Shin [36] and Pesaran et al. [37] have introduced a new method of dealing with co-integration. This approach is known as Autoregressive Distributed Lag (ARDL) approach. This approach has the advantage of avoiding the classification of variables into I (1) or I (0) and unlike the standard co-integration tests, there is no need for testing for unit root. Also the estimates are unbiased and efficient.

The ARDL approach uses two steps to estimate the long-run relationship. The first step is to determine whether a long-run relationship exist between the variables by considering each of the variables as a dependent variable and using F-test for the joint significance of lagged levels coefficients in each equation. In the second stage, is employed Akaike's Information Criterion (AIC) in selecting the lag length on each first differenced variable and then each equation is re estimated. If the co-integration results reveal that the variables are co-integrated then Vector Error Correction (VEC) model estimation is used otherwise Vector Auto-Regressive (VAR) model in the first difference is used given that all variables are I (1). These estimates provide the short-run coefficients (estimates of lagged first differenced variables in the ARDL model). Then their impact on environment pollution in the selected countries is also estimated.

$$
\Delta \mathrm{CO}_{2 \mathrm{t}}=\mathrm{a}_{0}+\sum \mathrm{a}_{\mathrm{gi}} \Delta \mathrm{CO}_{2 \mathrm{t}-\mathrm{I}}+\sum \mathrm{a}_{\mathrm{fi}} \Delta \mathrm{FDI}_{\mathrm{t}-\mathrm{I}}+\mathrm{a}_{1} \mathrm{CO}_{2 \mathrm{t}-1}+\mathrm{a}_{2} \mathrm{FDI}_{\mathrm{t}-1}+€_{1}
$$

Similar regression equations are written using growth and trade intensity as explanatory variables.

Another regression equation is specified for the interaction of FDI and Trade.

$$
\begin{aligned}
& \Delta \mathrm{CO}_{2 \mathrm{t}}=\mathrm{d}_{0}+\sum \mathrm{d}_{\mathrm{gi}} \Delta \mathrm{CO}_{2 \mathrm{t}-\mathrm{I}}+\sum \mathrm{d}_{\mathrm{fi}} \Delta \mathrm{FDI}_{\mathrm{t}-\mathrm{I}}+\sum \mathrm{d}_{\mathrm{ti}} \Delta \text { trade }_{\mathrm{t}-\mathrm{I}}+ \\
& +\mathrm{d}_{1} \mathrm{FDI}_{\mathrm{t}-1}+\mathrm{d}_{2} \operatorname{trade}_{\mathrm{t}-1}+\mathrm{d}_{3} \mathrm{CO}_{2 \mathrm{t}-1}+\mathrm{d}_{4} \text { FDI }_{\mathrm{t}-\mathrm{I}} \cdot \operatorname{Trade}_{\mathrm{t}-1}+€_{4} \\
& \text { The Null hypothesis } \mathrm{H}_{0}: \mathrm{a}_{\mathrm{i}}=0, \mathrm{~d}_{\mathrm{i}}=0 \\
& \text { Alternate Hypothesis } \mathrm{H}_{1}: \mathrm{a}_{\mathrm{i}} \neq 0, \mathrm{~d}_{\mathrm{i}} \neq 0
\end{aligned}
$$

The null hypothesis of non-existence of long-run relationship, that is, no co integration among the variables in the equation can be rejected if the computed value of $\mathrm{F}$ statistic is found to be higher than the upper bound of the critical values. On the other hand, if the computed F-value falls below the lower bound of the critical value then the null hypothesis of no co integration is accepted. In case the null hypothesis is rejected (that is, long-run relationship exists) then

The long-run coefficients are estimated by the estimation of the following equation.

$$
\left(\mathrm{CO}_{2}\right) \mathrm{t}=\mathrm{a}_{0}+\mathrm{a}_{1} \text { Growth }_{\mathrm{t}}+\mathrm{a}_{2} \text { FDIINT }_{\mathrm{t}}+\mathrm{a}_{3} \text { Tradeint }_{\mathrm{t}}+\mathrm{u}_{\mathrm{t}}
$$

\section{Empirical Results}

\section{Testing for time series properties (Results presented in the Appendix)}

To begin with, Variables are tested for the degree of stationarity, causality and co-integration. It is found that trade intensity, $\mathrm{CO}_{2}$ per capita and GDP per capita and FDI intensity are all I ( 1 at 5 percent level of significance). Causality test shows no evidence of unidirectional or pair wise causality between the variables. Variables are also not found co integrated by Johnson's test using different lags and ARDL approach.

\section{Estimation of growth equation}

Growth $=3.717-0.01$ Tradeint +0.764 FDIINT

t-value (0.87) (2.44)

$$
\mathrm{R}^{2}=0.14, \mathrm{D} . \mathrm{W}=1.72
$$

The regression result shows that the flow of foreign capital in the form of FDI has been helpful for economic growth. The coefficient of FDIINT is found as 0.764 which is quite high and statistically significant at 1 percent level of significance. This implies that a unit increase in FDIINT will lead to an increase of 0.764 in economic growth. On the other hand Trade is found very small and statistically insignificant to explain growth

\section{Testing for environment kuznet curve (EKC) hypothesis}

The best fitted equation (with AR (1) is found as under:

$\Delta \mathrm{CO}_{2}$ percap $=-0.12+0.075$ GDP growth -0.003 GDP growth square 
$\mathrm{t}$-values $=(3.36)(1.56)$

$$
\mathrm{R} 2=0.31, \mathrm{D} \cdot \mathrm{W}=2.02
$$

From the regression equation it follows that environment pollution as measured by $\mathrm{CO}_{2}$ per capita follows a parabolic path and slopes downwards. The coefficient of GDP growth in the equation is 0.075 that implies that a unit increase in GDP growth is causing an increase in $\mathrm{CO}_{2}$ emissions per capita by 0.075 which is quite significant. But the coefficient of GDP growth square variable is negative, although not statistically significant at 1 percent level of significance. This indicates a downward tendency of environment pollution after a certain level of national income. This implies that the EKC hypothesis is supported by the data.

\section{Testing pollution heaven hypothesis}

Data do not fully support the Pollution Heaven Hypothesis. All the variables considered (like the rising share of industry in GDP, domestic investment as a proportion of GDP and the share of polluting industries in the industrial output) except for the past values of changes in FDIINT, are found statistically insignificant (Figure 1).

\section{Estimation of the ARDL model}

Autoregressive Distributed Lag Estimates

ARDL $(0,1,0)$ selected based on Akaike Information Criterion

Dependent variable is $\mathrm{X} 3$ (Changes in $\mathrm{CO}_{2}$ emission per capita)

34 observations used for estimation from 1975 to 2008

Regressor Coefficient Standard Error T-Ratio [Prob]

X4 ( $\triangle$ FDIINT) - -.017595 .046317 -.37988[.707]

$\mathrm{X} 4(-1) .076019 .0426931 .7806[.085]$

X5 ( $\Delta$ Trade Int) -.0014190.0068334 -.20765[.837]

INPT .021448.16263.13189[.896]

TREND .0067189.0065136 1.0315[.311]

\section{R-Squared 0.4231}

S.E. of Regression .36931 F-stat. F (4,29) 1.2030[.331]

Mean of Dependent Variable .17614 S.D. of Dependent Variable .37382

Residual Sum of Squares 3.9552 Equation Log-likelihood -11.6714

Akaike Info. Criterion -16.6714 Schwarz Bayesian Criterion $-20.4873$

DW-statistic 2.1299

The regression result corresponding to equation 2 and the graph provides an overall good fit the regression results confirm that economic globalization had no significant effect on environment as judged by the F-value. The individual coefficients are mostly found statistically insignificant with different signs. This is attributed to the

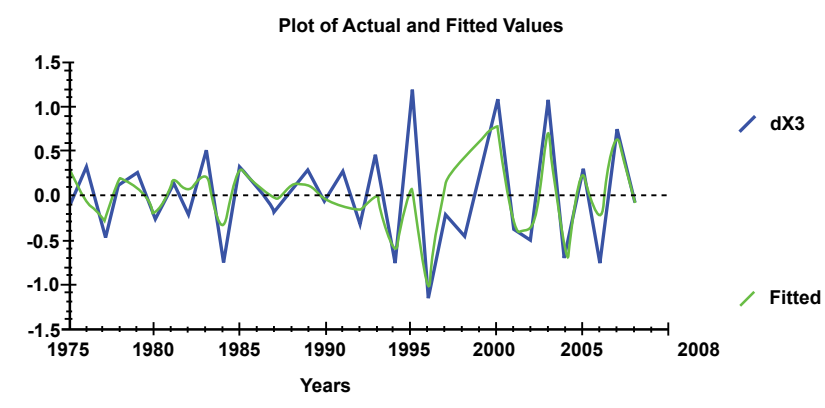

Figure 1:

mulicollinearity problem due to the presence of several lagged variables for each explanatory variable.

Further, as the F-value is found as statistically insignificant therefore the null hypothesis of no co integration is accepted and the long-run relationship is not estimated.

\section{Conclusions and Policy Implications}

- Pollution intensity, as measured by $\mathrm{CO}_{2}$ emissions per head has risen over time. But economic growth has not risen continuously over time. It shows cyclical ups and downs.

- Trade intensity has increased significantly

- Environment Kuznet Curve Hypothesis is supported by the data.

- Economic globalization policies are found to have adversely affected environment pollution indirectly through economic growth and not directly.

- Pollution Heaven Hypothesis is not fully supported by the data.

From above it can be concluded that economic globalization has helped in raising economic growth. There is also evidence to prove that the import of foreign capital or foreign technology has led to an increase in pollution intensity. But there is no evidence to show that trade liberalization has led to a significant rise in environment pollution. The trajectory of pollution intensity with respect to GDP per head and GDP growth is found parabolic in nature and shows that the down turn in pollution intensity has already started in Malaysia.

\section{Acknowledgement}

I express my sincere thanks to Dr. Norehan Abdullah (Economics Department, UUM) for helping us in data collection. Thanks are also due to Associate professor Dr. Jamal Ali (former Head of Economics Department UUM) for associating me in his Lead Research team and his encouragement. I express my sincere thanks to the anonymous referee of the paper for his comments and valuable suggestions.

\section{Reference}

1. World Bank (2008) World Development Indicators. Washington DC, World Bank.

2. World Bank (2006) World Development Indicators. Washington DC, World Bank.

3. Alguacil MT, Cuadros A, Orts V (2002) Foreign direct investment, exports and domestic performance in Mexico: a causality analysis. Econ Lett 77: 371-376.

4. Borensztein EJ, De Gregoriob J, Lee JW (1998) How Does Foreign Direct Investment Affect Economic Growth? J Int Econ 45: 115-135.

5. De Mello LR (1997) Foreign direct investment in developing countries and growth: A selective survey. Journal of Development Studiers 34: 1-34.

6. Gorg H, Greenway D (2004) Much ado about nothing? Do domestic firms really benefit from foreign direct investment. iza discussion paper no. 944. 
Citation: Agarwal RN (2012) Economic Globalisation, Growth and the Environment: Testing of Environment Kuznet Curve Hypothesis for Malaysia. J Bus Fin Aff 1:104. doi:10.4172/2167-0234.1000104

Page 8 of 8

7. Aitken BJ, Harrison AE (1999) Do Domestic Firms Benefit from direct foreign investment? Evidence from Venezuela. Am Econ Rev 89: 605-618.

8. Hansen H, Rand J (2006) On the Causal Links between FDI and Growth in Developing Countries. The World Economy 29: 21-41.

9. Levinson A, Taylor MS (2008) Unmasking the pollution haven effect. Int Econ Rev.

10. Edwards S (1993) Openness, trade liberalization, and growth in developing countries. J Econ Lit 31: 1358-1393.

11. Krueger AO (1997) Trade policy and economic development: How we learn Am Econ Rev 87: 1-22

12. Rodríguez F, Rodrik D (1999) Trade policy and economic growth: A skeptic's guide to the Cross-National Evidence. NBER Working Paper No. 7081

13. Harrigan J, Mosley P (1981) Evaluating the impact of World Bank structura adjustment lending: 1980-87. Journal of Development Studies.

14. Papageorgiou D, Michaely M, Choksi A (1991) Liberalizing Foreign Trade. Basi Blackwell.

15. Greenaway D, Sapsford D (1994) What does liberalisation do for exports and growth? Weltwirtschaftliches Archiv 130: 152-174.

16. Greenaway D (1993) Liberalising foreign trade through rose tinted glasses. Economic Journal 103: 208-222.

17. Makki SS, Somwaru A (2004) Impact of foreign direct investment and trade on economic growth: evidence from developing countries. Am J Agric Econ 86: 795 .

18. Jung WS, Marshall PJ (1985) Exports, growth and causality in developing countries. J Dev Econ 18: 1-12.

19. Lucas REB (1993) On the determinants of foreign direct investment: Evidence from East and Southeast. World Dev 21: 391-406.

20. Grossman GM, Helpman E (1991) Innovation and Growth in the Global Economy. MIT Press, Cambridge.

21. Marwah K, Tavakoli A (2004) The Effect of Foreign Capital and Imports on Economic Growth: Further Evidence from Four Asian Countries. J Asian Econ 15: $399-413$

22. Li X, Liu X (2005) Foreign Direct Investment and Economic Growth: An Increasingly Endogenous relationship. World Dev 33: 393-407.
23. Grossman GM, Krueger AB (1994) Economic Growth and the Environment Quarterly Journal of Economics 110: 353-377.

24. Seldon TM, Song D (1994) Environmental Quality and Development: Is There a Kuznets Curve for Air Pollution Emissions? J Environ Econ Manage 27: 147162

25. Antweiler W, Copeland BR, Taylor SM (2000) Is Free Trade Good for the Environment? Am Econ Rev 91: 877-908.

26. Kuznets S (1955) Economic Growth and income Inequality. Am Econ Rev 45 1-28.

27. Kuznets S (1966) Modern Economic Growth: Rate, Structure and Spread. New Haven and London: Yale University Press, xvii-529.

28. Dean JM (2002) Does trade liberalisation harm the environment? A new test The Canadian Journal of Economics 35: 819-842.

29. Copeland BR, Taylor SM (2004) Trade, growth and environment. J Econ Lit 42: 7-71.

30. Pethig R (1976) Pollution, welfare, and environmental policy in the theory of comparative advantage. J Environ Econ Manage 2: 160-169.

31. Xing Y, Kolstad C (2002) Do lax regulations attract foreign investment Economics of Finance and Trade 1: 76-81.

32. Eskeland GS, Harrison AE (2003) Moving to greener pastures? Multinationals and the pollution haven hypothesis. J Dev Econ 70: 1-23.

33. Jie He (2006) Pollution haven hypothesis and environmental impacts of foreign direct investment: The case of industrial emission of sulfur dioxide (SO2) in Chinese provinces. Ecological Economics 60: 228-45.

34. Baek J, Won Koo (2009) On the Dynamic Relationship between U.S. Farm Income and Macroeconomic Variables. Journal of Agricultural and Applied Economics 41: 521-528.

35. Acharya J (2009) FDI, Growth and the environment: evidence from India on $\mathrm{CO}_{2}$ emissions during the last two decades. J Econ Dev 34: 43-58.

36. Pesaran HM, Shin Y (1995) An Autoregressive Distributed Lag Modelling Approach to Cointegration Analysis University of Cambridge in its series Cambridge Working Papers in Economics with number 9514.

37. Pesaran MH, Shin Y, Smith R (2001) Bound testing approaches to the analysis of level relationships. J Appl Econom 16: 289-326. 